\title{
Romanismo e Germanismo no Código Civil Brasileiro*
}

\author{
eAlmixa do Couto e Pilva
}

Professor da Faculdade de Direito da UFRGS.

42

Os Códigos do século XIX e do iní cio deste século representam o ápi ce de uma linha evolutiva do pensamento jurídico que vê na norma jurí dica, especialmente na lei, a expressão da razão. $\mathrm{O}$ jusnaturalismo racionalista dos século XVII e XVIII e a ruptura com o absolutismo, que encontra sua forma mais violenta na Revolução Francesa, cimentaram as bases culturais e políticas para o triunfo da ratio sobre a voluntas, acabando por colocar os indivíduos e o próprio Estado non sub homine, sed sub lege $e^{1}$. A luta entre razão e vontade era antiga. Toda a baixa idade média se apaixona vivamente com as in termináveis discussões teológicas sobre se Deus seria prisioneiro da razão ou, se quisesse, tudo poderia, inclusive a transformação do pecado em virtude 2 . À imagem e semelhança de Deus concebido como von tade, liberto dos ditames e dos condicionamentos da razão, molda-se, na história política, o monarca legibus solutus, tido e havido como lex animata sobre a terra, cujo desejo legis habet vigorem, pois era dominus mundi, caput orbis e pater omnium, segundo a terminologia colhida no Corpus Iuris e na obra dos glosadores e comentaristas. A fórmula célebre de Luiz XIV, l'Etat c'est moi exprime esplendidamenbte essa identidade entre o governante e o Estado, que fazia da vontade do dirigente político a lei suprema

É de notar-se, entretanto, que a total sujeição do indivíduo à vontade do monarca só se dava nas relações estabelecidas com o Estado, pois não existia o Direito Público, assim como nós hoje o entendemos, e cuja parte mais importante consiste, precisamente, na rigorosa disciplina dos vínculos travados pelos particulares com o poder estatal. O que então se designava como Direito Público eram apenas as regras pertinentes à organização do Estado. Fica claro, pois, que as relações entre os indivíduos

- Conferência feita na Faculdade de Direito da UFMG, em 06.11.97, no Ciclo de Estudos Oitenta Anos de Código Civil.

1. Sobre isso, por todos, Carl Scmitt, Verfassungslehre, Berlin, Duncker \& Humblot, 1928, p.139 e ss.

2. Veja-se, Hans Welzel, Derecho Natural y Justicia Material,Madrid, Aguilar, 1957, p.101 e ss. 

simples laços de subordinação ou de sujeiromano, cujo respeito e acatamento não se razão que, no seu conjunto, espelhavam. hipótese, que a autoridade pública interfira e o Estado não eram relações jurídicas, mas ção, pois situavam-se, a rigor, numa área "sem Direito". O único direito que existia era, assim, o direito privado, a que o próprio Estado por vezes se submetia, como proprietário ou gestor de interesses patrimoniais, aparecendo então como "fiscus", seguindo em tudo as linhas do desenho da instituição romana. $O$ direito privado era, aliás, em grande medida, direito davam ratione Imperii, pois o Estado romano há muito desaparecera, mas imperium rationis, por força da excelência dos seus princípios e normas ou, numa palavra, da

O Estado de Direito que, na Europa continental surge com a Revolução Francesa, tem no princípio da legalidade um dos seus princípios estruturantes. $O$ campo até então "sem Direito", das relações entre os indivíduos e o Estado, passa a ser integralmente coberto e compreendido pelo Direito, não se admitindo, sob nenhuma na liberdade ou na propriedade dos indivíduos sem autorização legal. A lei que é criada para reger essas novas situações não tem, por certo, a garantia de racionalidade que a pátina do tempo e do longo percurso de experiência histórica davam aos preceitos do direito romano. Ela resulta, entretanto, da "vontade geral"do povo, como pretendia Rousseau ${ }^{3}$. E, precisamente por

ser manifestação do que quer a maioria dos cidadãos, muito dificilmente se desviará da razão. $O$ consenso democraticamente estabelecido impunha-lhe, de certo modo,a marca e o selo da racionalidade. Só muito mais tarde é que se compreenderá - e os horrores do nazismo serão decisivos para que isso ocorra - que a lei nem sempre é justa e que o direito positivo nem sempre corresponde aos ideais de justiça.

2. As grande codificações do século passado e as do início deste século realizamse numa fase em que as etapas da evolução do direito que sucintamente descrevi estão, senão completas, pelos menos em final de elaboração. Já se encontra, então, de qualquer maneira, consolidado, ao influxo das idéias de Rousseau, o novo conceito de lei. E é sob a forma de lei que os códigos serão editados. Pode-se dizer, assim, que as codificações submeteram-se a duplo teste de racionalidade. Por um lado porque os códigos acolhem nos seus textos, como realçado, um conjunto de normas cuja adequação ao corpo social em larga parte estava provada e comprovada por quase dois de mil anos de aplicação, não se podendo supor ou imaginar que aquele complexo de regras fosse contrário à razão. $\mathrm{E}$, por outro, porque, assumindo eles a natureza de lei, a expressão da vontade geral, convertiam-se desde logo na razão sem paixão de que já falava Aristóteles. Justiça e lei, nesse contexto, tornam-se noções coincidentes. A justiça está revelada no direito positivo.

3. Du Contrat Social, Livro II, cap. VI : "Sur cette idée, on voit à l'instant qu'il ne faut plus demander à qui il appartient de faire des lois, puisqu'elles sont des actes de la volonté générale; ni si le prince est au-dessus des lois, puisqu'l est membre de l'Etat; ni si la loi peut être injuste, puisque nuI n'est injuste envers lui méme; ni comment on est libre et soumis aux lois, puisqu'elles ne sont que des registres de nos volontés"(o destaque é nosso).

Revista da Faculdade de Direito da UFRGS, v. 13, 1997
Dessa maneira, os postulados racionalistas transpostos para a órbita do Direito conduziram, numa evolução natural e por vertentes distintas, ao positivismo jurídico, árvore que tem, nas codificações modernas, talvez os seus mais belos frutos. Bem por isto os códigos foram concebidos como obras destinadas à perenidade. São textos que se inculcam como exaustivos e definitivos, isentos de lacunas, a que os juizes e aplicadores estão jungidos por laços de estrita dependência. A essas considerações deverá ainda acrescentar-se que os Códigos mais recentes, como é o caso do nosso Código Civil, foram tributários do gigantesco esforço de análise e sistematização empreendido pela pandectística alemã do século XIX, que, trabalhando de modo especial sobre o direito romano, acentuou racionalidade de suas normas. Na verdade, o cientificismo jurídico, que foi o método de que se serviu a pandectística e que encontrou sua expressão maior na Begriffsjuriprudenz, se propunha a organizar e articular toda a matéria jurídica num sistema completo, limado e polido outra vez pela razão, e tão densamente fechado que impossibilitasse o juiz, ele próprio formado nessa ciência jurídica, de rebelar-se contra a sua lógica interna.

3. O caráter de monumento cultural, que se predicava aos códigos e até mesconsideravelmente $o$ aspecto $d a$ mo às grandes consolidações de épocas remotas, exigia que suas normas fossem enunciadas com clareza, precisão e apuro de linguagem. Cícero refere que, criança, aprendera de cor, na escola, as XII Tábuas, cujas regras eram fáceis de guardar na memória, pela sua concisão e ritmo. Stendhal dizia que costumava ler o Code Civil, para aprimorar o estilo. Rui Barbosa, na crítica que fez, no Senado, ao projeto de Código Civil, deixa de lado as questões jurídicas e limita-se a apontar os erros ou imprecisões vernaculares, dando causa a imensa e bem conhecida polêmica. Esses três testemunhos, feitos em três momentos históricos, mostram bem que a obra legislativa com a superior vocação de perenidade que possuem as grandes consolidações e, mais ainda do que elas, os códigos, precisava ser obra perfeita, tanto pelo conteúdo como pela forma.

É nessa moldura de idéias e concepções que é editado em 1916 e passa a viger, em 1917, o Código Civil Brasileiro. Conquanto seja codificação que se realiza e completa na segunda década deste século, reflete o clima e a atmosfera cultural do século anterior, tingindo-se assim, já no seu nascimento, de um certo anacronismo, como tem sido reconhecido ${ }^{4}$. Volvidos mais de oitenta anos do término de sua elaboração e do início da sua vigência, quando já se encontram apagados ou esmaecidos mui-
4. Clovis V. do Couto e Silva, Le Droit Civil Brésilien - Aperçu Historique et Perspective d'Avenir, in Quaderni Fiorentini, 18 (1989), p.155 ou, em versão portuguesa, mais recentemente, in O Direito Privado Brasileiro na Visão de Clóvis do Couto e Silva, Porto Gustav Boehmer : "Em seu sistema, técnica legislativa e estilo, bem como no seu 'espiríto' polifico, social e económico, o BGB é muito mais um filho do século XIX do que mãe do século XX' (Einführung in das Bürgerliche Recht,Tübingen, J.C.B.Mohr, 1965, p.83", repetindo, de resto, um juízo de Franz Wieacker, que via no BGB um fruto e não uma semente do pensamento jurídico (História do Direito Privado Moderno, Lisboa, Gulbenkian, 1980, p.548). 
tos dos traços que eram fortes e vivos à época da sua entrada em vigor, como a fé inabalável na ciência, a crença no positivismo jurídico e no valor sem contraste da dogmática jurídica, a identidade entre direito positivo e justiça ou mesmo entre lei e justiça ou lei e razão, quando, enfim, se põe seriamente em dúvida a utilidade das codificações, havendo quem diga, como Natalino Irti ${ }^{5}$, que estamos vivendo a época da "descodificação", a preocupação em identificar qual a carga de romanismo e de germanismo que se transmitiu ao nosso Código Civil revela, é obvio, preocupação eminentemente histórica.

4. Para essa tarefa, que se poderia chamar de genealogia cultural, cumpre, em primeiro lugar, que se esclareça o que há de se entender por romanismo ou germanismo. É por todos sabido que há considerável influência do direito romano, assim como também, embora em menor medida, do direito germânico no Código Civil Brasileiro. As dúvidas e dificuldades começam a surgir, porém, quando se tem presente o fato de que o direito romano consiste numa experiência, como direito da nação romana, de aproximadamente mil anos. Após o ocaso do Império Romano do ocidente, ele sobrevive ainda, embora em forma vulgar, decadente, degradado e corrompido, como direito dos povos bárbaros que dominam a Europa e, igualmente, no direito bizantino. No século XII, com Irnério e a Escola de Bolonha, é ele redescoberto e reestudado, para ser, depois, recebido como direito co- mum, de caráter subsidiário, na maior parte dos países europeus, formando, com a filosofia grega e a religião cristã, a base de cultura da assim chamada civilização ocidental.

Houve, portanto, vários direitos romanos. Sem preocupação de exaustividade, pode-se falar num direito romano do período arcaico, em outro do período clássico, em outro do período pós-clássico, em outro da codificação justinianéia,em outro dos glosadores,em outro dos comentaristas, em outro da pandectística alemã do século XIX. Dessas distintas expressões do direito romano é assente que a mais pura é a que corresponde ao período clássico, ou seja, o período que compreende os dois primeiros séculos do Principado, do mesmo modo como não se discute que a mais científica é a da pandectística. $\mathrm{O}$ direito romano do período clássico é uma sistema jurídico aberto,como o chamou Fritz Schulz, criando a distinção, que faria sucesso, entre sistemas jurídicos abertos e fechados ${ }^{6}$,embora nem aqueles sejam inteiramente abertos e nem estes completamente fechados. Os Códigos, sabidamente, dão origem a sistemas jurídicos fechados, na medida em que o aplicador parte das normas nele contidas, tratando de fazer a subsunção do caso concreto nesses preceitos. Nos sistemas abertos, a autoridade investida de dizer o direito parte do caso, chegando-se, pelos precedentes acumulados e por um processo de prode normas jurídicas? ${ }^{7}$ A frase de Paulo, non gressiva abstração, à fixação de um elenco

\section{L'Età della Decodificazione, Milano, Giuffì, 1989.}

6. Geschichte der Römische Rechtswissenschaft, Weimar, Herrmann Böhlau, 1961, p. 83-84.

7. Max Kaser, Sur la Méthode des Jurisconsultes Romains, in Romanitas, vol.5, p. 106-123.

Revista da Faculdade de Direito da UFRGS, v. 13, 1997 ex regula ius summatur, sed ex iure quod est regula fiat ${ }^{8}$ reflete exemplarmente a importância primordial do caso na construção do sistema jurídico romano e a forma mentis dos juristas clássicos. Assim, ainda que o direito romano clássico tivesse sofrido, sob Adriano e com o Edictum Perpetuum, uma significativa redução da "abertura" do sistema, não foi ele, entretanto, o que acabou por influenciar o Código Civil Brasileiro. Para que bem se compreenda a questão, deve-se esclarecer, a esta altura, que, exceto a fixação, feita por Sálvio Juliano, dos editos dos pretores no Edictum Perpetuum, o direito clássico romano, a seu tempo, jamais foi consolidado ou codificado. Como direito de juristas, consistia principalmente em manifestações esparsas de jurisconsultos, que conhecemos tão somente pelo Digesto, que é a parte mais importante do Corpus Iuris Civilis, e assim mesmo de uma forma muito imperfeita. A reprodução, no Digesto, das opiniões dos jurisconsultos freqüentemente não respeita a pureza original. Os fragmentos das obras clássicas sofrem, por vezes, mutilações. Outras vezes são submetidos a modificações ou acréscimos, conhecidos como interpolações, cuja identificação nem sempre é fácil de fazer, desafiando muitas delas, até hoje, a argúcia e a ciência dos eruditos. Desse modo, o legado que o direito romano deixou ao nosso Código Civil não consistiu no conjunto de instituições, idéias e conceitos tal como fo-

8. $D .50,17,1$

9. Sobre isso, por todos, o magnífico ensaio de Guilherme Braga da Cruz, O Direito Subsidiário na História do Direito Português, in Revista da Consultoria Geral do Estado do Rio Grande do Sul, vol. 10 p.11 e ss.

10. idem, ibidem, p. 18 e ss.

11. idem, ibidem, p. 24 e ss;. Marcelo Caetano, História do Direito Português, Lisboa/São Paulo, Verbo, 1981,p.340 e283 e ss. ram elaborados ou aperfeiçoados na sua idade de ouro.

5. O direito romano chegou ao nosso Código Civil sobretudo pela obra da codificação justinianeia, filtrada pela experiência jurídica portuguesa, na qual, quase desde as suas origens, exerceu importantíssima função como direito subsidiário, ao lado do direito canônico ${ }^{9}$. Nota Guilherme Braga da Cruz que já no decurso do século XIII,ao completar-se o seu primeiro século como reino independente, Portugal se liberta do direito leonês e castelhano para decididamente incorporar-se ao movimento que, tendo centro dominante em Bolonha, irradia por quase toda a Europa continental o direito romano justinianeu e o direito canônico $^{10}$. É ainda o mesmo reputado autor quem observa que a intensa atividade legislativa verificada nos reinados de Afonso II e Afonso III é toda ela profundamente vincada pelo direito justinianeu, assim como pelo direito canônico. E esse quadro completa-se, sob D. Dinis, no ocaso do século XIII, com a criação do Estudo Geral, semente de onde brotaria a universidade portuguesa, dentre cujas disciplinas o direito romano e o canônico ocupavam posição de realce ${ }^{11}$. Levará, porém, algum tempo até que o direito português passe a beber diretamente nas fontes romanas. A estas tinha acesso, apenas, o reduzido número das pessoas que liam latim e que haviam tido a ocasião de estudar em universidades es-

Revista da Faculdade de Direito da UFRGS, v. 13, 1997 
trangeiras ou na recém criada universidade portuguesa. Os demais, quando aplicados aos misteres da justiça ou da administração do reino, estabeleciam contato com o direito romano ou com o direito canônico mediante textos que só indiretamente os espelhavam, como sucedia com as coletâneas jurídicas castelhanas, ordenadas por D.Afonso o Sábio, o Fuero Real e as Siete Partidas, manuseadas no original ou em tradução portuguesa ${ }^{12}$

6. Fosse como fosse, o certo é que o incipiente direito português era ainda um corpo de normas muito incompleto e lacunoso, cujos defeitos se faziam mais evidentes porque estendido sobre um direito subsidiário que se apresentava como um tecido denso, rico, de extraordinária abrangência e que respondia, quase sempre, às dúvidas e questões postas a cada momento pela opulenta e variada sucessão dos casos concretos. Não é de espantar, portanto, que, nessas circunstâncias, a vida jurídica se pautasse prevalentemente pelo direito subsidiário, representando o direito propriamente lusitano um modesto papel.

Com o andar do tempo, entretanto, cresce o número dos interessados em conhecer o direito romano nos seus próprios mananciais, passando esses estudiosos a recriminar as obras de segunda mão que o divulgavam e a protestar, sobretudo, contra a aplicação das Siete Partidas às causas em julgamento, quando elas deveriam ser decididas pelos preceitos romanos, assim como estavam inscritos na obra de Justiniano. À pressão dessas exigências é

12. idem, ibidem, p.29. que começam a circular, no século $\mathrm{XV}$, traduções da obra legislativa justinianeia e de textos do direito canônico, bem como da Glosa de Acúrsio e dos Comentários de Bártolo, afastando-se definitivamente, do campo do direito subsidiário, as contribuições do direito castelhano. A partir daí os conflitos que se irão estabelecer serão entre o direito romano e o direito canônico, por um lado e, por outro, entre o direito português e o direito romano e canônico, como direito subsidiário. Com a promulgação das Ordenações Afonsinas, em 1446 ou 1447, este último conflito é solvido com a declaração da prevalência do direito português sobre o direito subsidiário.Esse estado de coisas perdura nas Ordenações Manuelinas, do início do século XVI e nas Ordenações Filipinas, do começo do século XVII(1603) que tornam a afirmar a preeminência das fontes imediatas do Direito, consistentes nas leis nacionais, estilos da Corte e costumes do Reino sobre o direito subsidiário. Na hipótese de o direito romano e o direito canônico não terem solução para o caso concreto, dever-se-ia recorrer à Glosa Magna de Acúrsio ou à opinião de Bártolo. Contudo, desde as Ordenações Manuelinas, nas suas duas versões, a autoridade dos textos de Acúrsio e Bártolo ficou condicionada a sua concordância com a opinião comum dos doutores.

7. Em breves linhas e seguindo sempre os passos de Braga da Cruz, é assim que se descreve, sob o aspecto formal, a questão da hierarquia das fontes do direito em Portugal e, desde o descobrimento, também, por conseqüência, no Brasil. Materialmente, entretanto, a prática jurídica muito comumente subvertia essa hierarquia, dando primazia ao direito subsidiário, notadamente ao direito romano, em detrimento do direito nacional.

Não se modifica essa situação até o advento das reformas pombalinas, com edição da Lei de 18 de agosto de 1769 , conhecida como Lei da Boa Razão e da Carta de Lei, que, em 1772, aprovou os novos Estatutos da Universidade de Coimbra. Tais reformas orientam-se pelas idéias que amplamente circulavam no século das luzes e que, na área jurídica, se exprimem no jusnaturalismo racionalista e no usus modernus pandectarum. A boa razão, a recta ratio, passa a ser, desde então o critério por excelência a comandar a interpretação e a integração de lacunas. $O$ direito romano só persiste como direito subsidiário quando expresse a razão natural, a qual, pouco adiante, já nos primeiros anos do século XIX poderá estar mais bem refletida na legislação de outros povos, especialmente nas codificações e, dentre estas, no Código de Napoleão, que é o que goza de maior prestígio. Com a edição do Código Civil Português, de 1867, cessa, em Portugal, a vigência das Ordenações Filipinas e, pois, do direito romano como direito subsidiário.

8. No Brasil, com a Independência foi desde logo adotada a legislação portu guesa $a^{13}$, como medida que se pretendia fosse manifestamente provisória, pois a Constituição Imperial de 1824 , no seu art.
179 , parágrafo 18 , solene e incisivamente determinava que se organizasse "quanto antes um código civil e criminal, fundado nas sólidas bases da justiça e eqüidade". O Código Criminal, efetivamente, não demorou muito a vir. Foi editado em 1830 e quase vinte anos após ganhava a nação o seu Código Comercial. No que toca, porém, ao Código Civil, circunstâncias várias, que não cabe nesta ocasião retraçar, retardaram sua feitura. Será indispensável, entretanto, aqui mais uma vez prestar homenagem ao gênio de Teixeira de Freitas que, com a sua Consolidação das Leis Civis e o seu Esboço, pôsse adiante do seu tempo, inserindo em sua obra as propostas pioneiras de uma parte geral para o Código e a unificação das obrigações civis e comerciais, muito antes de o Código Civil alemão, de 1900, e o Código Suisso das Obrigações, de 1912, respectivamente, adotarem uma e outra dessas soluções.

O espaço de quase um século transcorrido entre a Constituição de 1824 e o nosso Código Civil alongou exageradamente a vigência, no campo das relações privadas, de um verdadeiro mosaico normativo, confuso,impreciso, caótico, no qual as Ordenações Filipinas, de 1603, eram a parte principal, a que se misturavam, porém, textos de legislação portuguesa e brasileira, tendo ainda como direito subsidiário,a que se recorria a cada passo, não apenas o direito romano, com os condicionamentos introduzidos pela Lei da Boa 
Razão, mas também o que se convencionou chamar o direito dos povos cultos ${ }^{14}$.

Carlos de Carvalho, no prefácio que escreveu em 1889 para sua Nova Consolidação das Leis Civis, assim retrata o direito brasileiro daquele fim de século, fazendo pensar no tormento que deveria ser para os juizes, advogados, estudantes e os que, por quaisquer motivos, devessem aprendê-lo, interpretá-lo e aplicá-lo: "O direito romano", diz ele, "principalmente pela lição alemã de Heineccio, Waldeck, Savigny, Puchta, Muhlenbruch, Mackeldey e Varkoenig, para não falar nos compêndios franceses e belgas, $o$ direito francês por Domat e Pothier e pelos comentários doutrinais do Código de Napoleão, isto é, pelo método exegético, Merlin e Dalloz e os códigos de outras nações, pela Concordance tos de ensino. Coelho da Rocha, suprindo as lacunas com o Código da Prússia, Correa Telles, com receio de passar por inovador, recorrendo à opinião dos doutores velhos e já falecidos. Borges Cameiro pedindo a Heineccio subsídios para formar o jus constitutum eram, com Mello Freire e Almeida Lobão, os guias espirituais do foro, servindo de artigos de ornamentação os velhos e poeirentos praxistas". Por outro lado, prossegue, "não há preceito jurídico por mais simples, evidente ou intuitivo, que não se sinta obrigado a comparecer perante os tribunais acompanhado de numeroso séquito. As regras de direito não circulam nem são recebidas pela força da lei, de seu espírito ou princípios mas pelo número de de St. Joseph, constituiam em regra os elemen-

endossantes, nacionais poucos e estrangeiros muitos, de preferência italianos e alemães" 15 .

9. As considerações até aqui feitas, destinadas a precisar, em ensaio apressado de história externa, quais as fontes romanas que deixaram sua marca no Código $\mathrm{Ci}$ vil Brasileiro e por que caminhos vieram até ele, deverão ser complementadas por outras notas, relacionadas com a história interna, nas quais se trate de identificar e descrever as instituições do direito romano que mereceram acolhida no mais prestigiado dos nossos códigos.

Antes, porém, para que esta exposição tenha um certo equilíbrio geométrico e não peque contra a simetria, far-se-á mister que se esclareça o que se deverá compreender por germanismo no nosso Código Civil

Germanismo, nesse contexto, poderá ser entendido, pelo menos de duas maneiras. De uma parte, como o conjunto de instituições, regras, práticas e costumes, de caráter jurídico, observados pelos povos germânicos, antes da recepção do direito romano, o que, na Alemanha, só tardiamente irá ocorrer. Na verdade, registra Koschaker, apenas a partir da metade do século XIV o direito romano começa a ser efetivamente estudado nas universidades alemãs e, mesmo assim, nessa época, tinha ele uma importância secundária, subordinado que era ao direito canônico, "porque só o direito canônico era necessário na práti作 pelo Governo Imperial em 1858, depois enriquecida, em 1877, de Adlamentos de autoria do mesmo jurisconsulfo, representava substancial alteraçäo na legislação filipina" (100 Anos de Ciência do Direito no Brasil, S.Paulo, Saraiva, 1973, p.5). Mesmo assim, o quadro normativo brasileiro carecia da precisão e segurança que o só o Código Civil viria a dar. 15. Rio de Janeiro, Francisco Alves, 1899, pp.VI e VIII.

Revista da Faculdade de Direito da UFRGS, v. 13, 1997 $c a^{\prime \prime}{ }^{16}$. Desde então se estabelece uma luta entre o direito germânico e o direito romano, de tal modo que as forças em oposição acabam por confundir-se e mesclar-se, formando, com as importantes contribuições do direito canônico, o direito comum, direito de especialistas, direito de juristas práticos, que alcançará seu apogeu, no século XVII, com o usus modernus pandectarum ${ }^{17}$

Com o advento da Escola Histórica, brotam dois ramos perfeitamente definidos, o dos germanistas e o dos romanistas, e não deixa de ser expressivo que, até hoje, uma das mundialmente mais reputadas revistas jurídicas no campo da história do Direito, a Revista da Fundação Savigny (Zeitschrift der Savigny Stiftung) seja dividida em duas áreas, a dedicada ao direito germânico (germanistiche Abteilung) e a voltada para o direito romano (romanistische Abteilung).

Alguns germanistas criticaram, por vezes em termos extraordinariamente ásperos, a recepção do direito romano na Alemanha. A recepção do direito romano é vista por eles como um descalabro, um desastre, uma verdadeira "desgraça nacional" (nationales Unglück), censuras que serão endossadas, depois, pelo nacional socialis$\mathrm{mo}^{18}$. Contudo, mesmo entre os estudiosos dedicados à recuperação ou à reconstrução histórica do direito genuinamente ale-

16. Europa y el Derecho Romano, Rev. de Der. Privado, Madrid, 1955, p.220.

17. Paul Koschaker, op. cit. p.332 e ss.

18. As críticas mais veementes à recepçăo provêm de Georg Beseler e August Friedrich Reyscher. Ao primeiro se deve, também, a qualificação do direito romano, na forma tratada pela pandectística, como "direito de juristas" (Juristenrechnt em oposição ao direito germânico, que seria "direito do povo" (Volksrecht"(Molitor/Schlosser, Grundzüge der Neuren Privatrechtsgeschichte Karlsruhe, C.F. Müller, 1975, p.73).Sobre as lutas entre romanistas e germanistas,bem como a posição do nazismo quanto à recepcão, Koschaker,op. cit., p.229 e ss.

19. op. cit, p. 448 .

20. id. ib., p. 448

mão, não são poucos os que mantiveram, face ao problema, posição de sensato equilíbrio, não se deixando levar pelo emocionalismo patriótico dos seus colegas mais exaltados.

$\mathrm{Na}$ escola histórica, a existência dessas duas tendências é de algum modo harmonizada pela presença muito forte do gênio de Savigny, que é a maior figura no cenário jurídico do século XIX. O conceito amplo de "espírito do povo" (Volksgeist), adotado por Savigny, partindo da idéia, como sublinha Wieacker, de que povo, "na verdade, não é a realidade política e social da naçāo histórica, mas um conceito cultural ideal - a comunidade espiritual e cultural ligada por uma cultura comum"19, permitiu que, à sua sombra, se desenvolvesse tanto a tendência que via no direito romano "um elemento essencial da vida jurídica alemã, entendida como processo cultural"20, quanto o movimento que prezava, sobretudo, a formação espontânea do direito nacional, consolidado especialmente pelo costume.

O primeiro caminho, o do romanismo, pelo qual Savigny demonstrava inequívoca simpatia, como atesta sua obra prodigiosa, levaria à ciência das Pandectas, ao cientificismo jurídico e à construção de um bem elaborado e rígido sistema do Direito Civil, enquanto o outro, 
o do germanismo, daria ênfase ao empirismo jurídico, ao direito criado ou revelado diretamente pelo povo e não por técnicos ou juristas, à imanência do Direito no próprio fato, à "natureza das coisas"(Natur der Sache), noção que tanta importância iria ter, mais tarde, na Filosofia do Direito alemã.

Numa fórmula sintética, nesse contraste, o romanismo seria um direito de juristas (Juristenrecht), ao passo que o germanismo um direito do povo (Volksrecht), para usar os termos do título de um livro famoso de Georg Beseler, um dos líderes da corrente germanista ${ }^{21}$.

Daí, no direito germânico da idade média, o especial relevo conferido aos julgamentos por grupos de jurados leigos, os chamados Schöffen (escabinos), cujas decisões, se não tinham o refinamento lógico que encontramos no raciocínio jurídico bem articulado das soluções do direito romano, emanavam, entretanto, de um sentimento ou de uma intuição de justiça, radicada no coração do povo ${ }^{22}$.

Ao caráter profundamente individualista do direito romano que encontrava, porém, seu último limite na estabilidade do Estado e no bem estar do povo, como revela o princípio salus publica suprema lex esto, contrapunha o direito germânico uma concepção de ordem social em que o indivíduo não é uma criatura abstrata, mas um ser que se define pela sua inserção na sua circunstância, na sua família, na sua cida-

de, na sua profissão, na sua experiência diária de vida ${ }^{23}$. Tais características explicam a forma matizada que assumem certas instituições jurídicas germânicas, que variam de lugar para lugar, ao sabor das praxes e costumes, mas onde está presente, quase sempre, um compromisso entre os benefícios e vantagens individuais e o bem comum.

A propriedade talvez constitua $o$ exemplo por excelência do que acabamos de afirmar. Não há uma propriedade imutável, única, igual em todas as situações. Ela se diferencia conforme os fins econômicos perseguidos ou a posição social do titular do direito, estando, de algum modo vinculada ao interesse coletivo. A regra célebre, estampada na Constituição de Weimar, "a propriedade obriga" (Eigentum verplichtet), não é, de modo algum, um corpo estranho na tradição jurídica alemã ou uma norma que tenha nascido totalmente despegada do passado cultural germânico. Bem ao contrário, ela surge, num determinado momento histórico, como resultado natural de uma antiga e constante tendência ${ }^{24}$.

10. Na visão global do Direito Privado, pode-se dizer que o romanismo se ocupou quase que exclusivamente do direito civil, ficando com o germanismo a construção da ciência alemã do direito comercial, do direito cambiário, do direito da corporação e das sociedades mercantís, do direito marítimo, do direito dos seguros

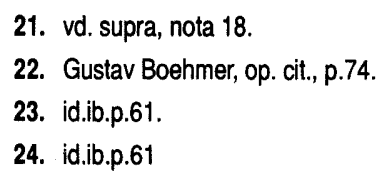

e de minas, entre outros mais ligados diretamente à vida econômica ${ }^{2526}$.A inclinação pelo comércio, que anima a população das cidades germânicas da idade média, perdura e se intensifica no curso do tempo, determinando o nascimento desses diferentes ramos do direito, em muitos dos quais os negócios jurídicos são geralmente abstratos, para permitir a rápida circulação dos bens e a segurança dos terceiros. As instituições germânicas teriam, assim, dado origem a um direito que, no século XIX, se dizia "mais moderno" do que o direito civil, porque mais em harmonia com a expansão e a diversidade dos negócios na sociedade capitalis$\mathrm{ta}^{27}$

11. Contudo, mesmo no direito civil, apesar do predomínio quase absoluto do direito romano após a recepção, aqui e ali as instituições jurídicas germânicas resistem e deixam sua marca no tecido normativo. Dentre elas talvez a mais importante é a que se prende aos testemunhos judiciais, do velho processo germânico, origem do registro imobiliário, que tanta importância terá na transmissão da propriedade imobiliária e na eficácia dos contratos.

Para a transmissão de domínio sobre imóveis exigia-se, em primeiro lugar, um negócio jurídico de alienação, chamado sala
( da origem gótica comum deu, em inglês, sale $\left.^{28}\right)$, sobre cuja natureza até hoje se discute, entendendo alguns que se tratava de um negócio jurídico do direito das obrigaçồes, como é, por exemplo, a compra e venda, e outros um negócio jurídico de direito real, como o acordo de transmissão do direito alemão dos nossos $\operatorname{dias}^{29}$.A esse acordo seguia-se a entrega corporal, a vestitura ou investitura, que se dava, nos primeiros tempos, no próprio lugar do imóvel. A correspondente entrega da posse, o afastamento corporal pelo alienante (exire), foi logo substituído por um acordo ou contrato sobre a perda da posse, que se realizava por uma declaração oral e, entre os francos, pela entrega de um bastão ou vara (festuca). Designava-se a isso de perfestucam se exitum dicere, exfestucatio, resignatio, e, posteriormente, Auflassung. No reino franco desenvolveu-se uma forma de tradição do direito romano vulgar, a traditio per cartam: o alienante entregava ao adquirente um documento de transmissão da propriedade.

Com o tempo, verifica-se um processo de espiritualização da vestitura, que se torna incorporal, ou seja, a transmissão ou a entrega da posse não necessita mais que ocorra no lugar do imóvel. Ela pode ser feita no tribunal. Inclina-se o direito
25. id ib p. 344. Também, Molitor/Schlosser op cit p.69 ess, especialmente p. 74

26. É interessante notar como essas concepçōes do germanismo, que acabaram por expressar-se no direito mercantil alemão, tiveram também decidida influência nos Estados Unidos, no Uniform Commercial Code, através de Karl Llewellyn. Veja-se, sobre isso, James Whitman, Commercial Law and the American Volk: a Note on Llewlyn's German Sources for the Uniform Commercial Code, in Yale Law Journal. vol.97 (1987), p.156 e ss.

27. Molitor/Schlosser, op. cit. p.74.

28. ct. Pontes de Miranda, Tratado de Direito Privado, Rio, Borsoi, 1955, vol 11, p.213

29. Cf.Brunner/v. Schwerin, Historia del Derecho Germanico, Barcelona, Labor, 1936, p.,197, nota 1, do trad. José Luiz Alvares Lopes. 
germânico, neste ponto, para um rumo e uma solução já conhecidos pelo direito romano, quais sejam os da utilização de institutos processuais para a obtenção de fins de direito material, como sucedia com a in iure cessio, em que as partes simulavam a existência de uma ação reivindicatória para obter a transmissão formal da propriedade.A tradição per cartam poderia também efetivar-se no tribunal.Com o surgimento dos chamados "livros de direito" em que se registravam os atos processuais, essa resignatio judicial assume considerável realce, pela força probatória absoluta do testemunho judicial e do documento judicial, que lhe emprestava os mesmos efeitos da coisa julgada.

Ao final desse iter histórico, o registro da resignatio nos livros oficiais é requisito essencial para a transmissão do domínio, nascendo, assim, o registro imobiliário moderno. A resignatio procedida nesses termos tinha o condão de atribuir ao adquirente, ao cabo de um período de ano e dia, a Gewere legítima, ou seja a total impossibilidade de impugnação da propriedade por terceiros ${ }^{30}$.

Ao direito germânico devem-se, igualmente, as distinções introduzidas no conceito romano de posse, - o qual, aliás, com a recepção, acabou prevalecendo no direito alemão- e que separam a posse imediata da posse mediata. Como observa Betti, tal discrime revela um "processo de espiritualização do 'poder de fato', que é adequado para facilitar a circulação das coisas" 31 .

Outra contribuição importante do direito germânico ao direito civil foi a distinção entre débito (Schuld) e responsabilidade (Haftung) ${ }^{32}$, pela qual se evidencia que o responsável pode não ser o devedor, o que acontece, por exemplo, quando um terceiro (que não é devedor) dá em hipoteca um imóvel seu em garantia de dívida de terceiro ( que é devedor, mas não é reponsável).

12. E aqui convém já mencionar o segundo sentido que a palavra germanismo pode assumir, certamente não na Alemanha, mas entre nós, quando referida a influências sofridas pela nossa cultura ou, especificamente, para o que aqui nos interessa, pelo Código Civil Brasileiro. Nessa outra acepção, germanismo será interpretado num sentido mais largo, abrangendo as criações do pensamento jurídico alemão, posteriores à recepção, que foram acolhidas na nossa codificação, por inteiro ou modificadas, ou que a ela serviram de inspiração. Em tal perspectiva, a investigação dos traços deixados pelo germanismo, sempre tomado nessa peculiar acepção, no Código Civil de 1917, terá necessariamente de considerar a contribuição romanista da ciência jurídica alemã, que começa com Savigny, e que depois se irá desenvolver notavelmente com a pandectística, na qual brilha singularmente a obra de Windscheid, culminando com o BGB (Bürgerliches

30. Em toda essa descrição da origem do registro imobiliário seguimos Brunner/v.Schwerin, op.cit, p.197 e ss.

31. op. cit., p. 100.

32. Molitor/Schlosser, op. cit., p.74.

Revista da Faculdade de Direito da UFRGS, v. 13, 1997

Gesetzbuch), concluído em 1.896, mas que entrou em vigência em 1.900. Dizendo de outro modo, por germanismo, nesse segundo sentido, não se considerará a matéria sobre a qual trabalhou a ciência jurídica alemã ( matéria que era, como se viu, predominantemente romana), mas apenas $\mathrm{e}$ exclusivamente essa ciência jurídica

Quem se debruçar sobre a obra de Teixeira de Freitas, ou dos grandes juristas brasileiros da fase imediatamente anterior à da elaboração do nosso Código Civil, como Lafayette Rodrigues Pereira, Lacerda de Almeida , Eduardo Espínola e o próprio Clóvis Bevilaqua, logo perceberá a intimidade que tinham esses autores com a obra dos mais célebres juristas germânicos do seu tempo ${ }^{33}$. Deve dizer-se, porém, a bem da verdade, que essa intimidade se estendia também aos juristas eminentes, de expressão francesa ou italiana, para não falar nos portugueses. De certa maneira, repetia-se, assim, num plano mais elevado, em que os exageros eram eliminados por critérios críticos bem mais estritos, o que acontecia nas práticas forenses, onde os advogados, no afã de convencerem os juizes, invocavam farta doutrina estrangeira, reiterando uma praxe que se consolidara desde a Lei da Boa Razão e que justificava a caricatura de Carlos de Carvalho, em trecho que aqui já transcreví.

É oportuno que se saliente, no entanto, que a literatura jurídica alemã do século XIX qualitativamente sobrelevava a todas as outras, contrabalançando, pode-

rosamente, a influência que o Código Civil Francês e, em menor medida, o Código Civil Austríaco, de 1.811, exerceram sobre a legislação de outros povos.

Savigny, os pandectistas e seus sucessores, como sinala Emilio Betti, deram origem a uma "doutrina que combinou pela primeira vez os métodos históricos com os de uma dogmática sistemática e elaborou os conceitos jurídicos e os princípios gerais com um grau de clareza e de refinamento que anteriormente nunca tinha sido atingido" ${ }^{34}$. Foram os alemães, sem sombra de dúvida, os pais da ciência jurídica moderna, que encontra seu coroamento no BGB. Comparada essa monumental obra legislativa com as duas grandes primeiras codificações do início do século XIX, de imediato se destaca a superior qualidade técnica do BGB. O desenvolvimento científico do Direito, ocorrido na Alemanha, no curso do século passado, bem como as modificações culturais, econômicas e políticas por que passou o mundo nesse mesmo período de tempo, envelheceram e desgastaram, prematura e severamente, tanto o Código Civil francês quanto o austríaco.

Muito embora fossem eles as expressões mais altas do jusnaturalismo racionalista, elaborados, portanto, e postos em vigor com a pretensão de haverem cristalizado uma ordem jurídica abstrata e atemporal, que deveria servir a todos os povos, motivo pelo qual os intérpretes e aplicadores estavam proibidos de desnaturálos, muito cedo se verificou que eles não

33. Sobre a influência de Savigny na obra de Teixeira de Freitas, veja-se Clóvis V. do Couto e Silva, op. cit. p. 153 e ss. e nota 8 . 34. Système du Code Civil Allemand, Milano, Giuffrè, 1965, p.12.

Revista da Faculdade de Direjte da $a_{G} U F R G S$, v. 13, 1997 FACULDACE CE DLRETL BIBLIOTECA 
representavam o que hoje se poderia chamar de o "fim da história" jurídica. E quem se incumbirá de mostrar isso será, precisamente, a Escola Histórica, em todos os seus desdobramentos, e o novo humanismo que a caracteriza, ou seja, em poucas palavras, a ciência jurídica alemã do século XIX.

Um dos mais notáveis juristas do nosso tempo, ao efetuar o cotejo entre o BGB e aquelas outros códigos, observa que estes "não haviam estabelecido regras sobre as pessoas jurídicas (o que foi objeto de meditação pela doutrina alemã); a fundação lies é desconhecida, do mesmo modo como a noção de atos jurídicos e de suas diferentes categorias; seu tratamento da nulidade dos atos carece de precisão; eles não contêm normas sobre a conclusão dos contratos, a representação, a estipulação em favor de terceiros, a cessão de crédito e a assunção de divida; a causa e o ato abstrato são apresentados desde então" (desde o BGB) "sob uma nova luz; do mesmo modo como o enriquecimento sem causa e a posse" 35 .

Não pode, pois, causar surpresa que muitas dessas imperfeições apontadas nos Códigos Civis francês e austríaco ( e o mesmo se poderá dizer de outros códigos que receberam sua direta influência, no século passado) estejam ausentes no nosso Código Civil, como também certamente não espantará que nele hajam sido acolhidos progressos técnicos revelados ou introduzidos pela ciência jurídica alemã, não só em razão da sua excelência, mas também porque a chamada Escola do Recife, sob a li-

derança de Tobias Barreto, dera considerável importância e prestígio, entre nós, à cultura germânica no campo do Direito. Cabe lembrar, nesta ordem de considerações, que Clovis Bevilaqua, o autor do anteprojeto do Código Civil brasileiro, era professor da Faculdade de Direito do Recife.

Ainda deverá dizer-se, nesta mesma linha de observações, que seria perfeitamente natural, como o foi, que, em razão da sua maior proximidade histórica, a ciência jurídica alemã, afinal cristalizada no BGB, tivesse sobre o Código Civil Brasileiro uma influência em muitos aspectos mais expressiva do que a do Code Napoléon ${ }^{36}$. O Código Civil Alemão e o nosso, diferentemente dos dois outros, propunham-se a ser o coroamento e a conclusão de uma prolongada fase de vigência do ius commune, muito mais do que instrumentos revolucionários de mudança da sociedade. Apesar de que a preocupação com a segurança jurídica dos indivíduos estivesse evidentemente entre as motivações principais de ambas as codificações, pois, é óbvio que a maior definição e clareza da ordem jurídica, operada pela codificação, teria essa conseqüência imediata, faltava-lhes a missão propedêutica de educar o povo em um novo credo. Talvez seja nessa circunstância que se deverá buscar a explicação para o diminuto entusiasmo popular (se é que algum entusiasmo efetivamente existiu) com que foram recebidos quer o Código Civil Ale-

\section{5. id.ib., p.13.}

36. É claro que isso se explica, também, por outras razōes, entre as quais não são as menores a importância e o prestígio da obra de Teixeira de Freitas (cf. Clóvis do Couto e Silva, op. cit., p. 153).

Revista da Faculdade de Direito da UFRGS, v. 13, 1997 mão quer o nosso, em contraste com o que ocorreu sobretudo com o Código Civil francês.

13. Já se deixa assim perceber que o germanismo a que prestou tributo e homenagem o Código Civil Brasileiro foi sobretudo o que pode ser identificado com a ciência jurídica alemã do século XIX (portanto o que é assim entendido fora da Alemanha), muito mais do que aquele outro, de caráter material ou substancial, consistente nas instituições jurídicas germânicas anteriores à recepção. Desde logo será de justiça assinalar, entretanto, que jamais a influência alemã sobre o Código Civil brasileiro que, como se viu, é irrecusável, fazem daquela nossa obra legislativa uma imitação servil do Código alemão, como aconteceu com a codificação realizada por outras nações como, por exemplo, o Japão. Muito longe disso. O Código Civil brasileiro é um código afinado com a ciência jurídica do seu tempo e, por isso mesmo, não poderia nunca desconhecer as ricas vertentes da ciência jurídica alemã, de que se utilizou, entretanto, sempre com muita prudência e comedimento, temperando suas contribuições com a tradição luso-brasileira ou com a pureza dos ensinamentos do direito romano, onde o BGB deles se desviou, como sucedeu, por exemplo, ao construir, como abstrata, a transferência da propriedade imobiliária, ou com os empréstimos tomados ao Code Civil, que parecem

numerosos, mas que talvez sejam muito mais recortados do direito romano com a expressão que lhe deu o direito francês ${ }^{37}$. Essa posição de equilíbrio e de relativa independência que guardou o nosso Código Civil, não apenas com respeito ao $\mathrm{BGB}$, mas também com relação a outros códigos famosos do século passado, como o napoleônico, o austríaco, o italiano e o português, para mencionar apenas alguns dos mais conhecidos, é que o erguem à condição indiscutível de ser um dos mais originais dessa segunda geração de códigos, que se inaugura precisamente com o $\mathrm{BGB}^{38}$

12. No pertinente ao sistema adotado pelo Código Civil brasileiro, ele se afasta do contido no Esboço de Teixeira de Freitas, para aproximar-se do geralmente usado no direito das pandectas germânico. Sua gênese deve ser buscada nos Apontamentos para o Projeto do Código Civil Brasileiro, apresentados por Joaquim Felício dos Santos, em 1881, que dividiam a matéria em uma parte geral, subdividida em três livros, que tratavam das pessoas em geral, das coisas em geral e dos atos jurídicos em geral, e de uma parte especial, por sua vez também subdividida em três livros, que se ocupavam das pessoas em especial, das coisas em especial e dos atos jurídicos em especial, tudo isso era precedido por um "Título Preliminar", que dispunha sobre a publicação, efeitos e aplicação das leis em geral $^{39}$. A influência germânica acentuou-

37. Pontes de Miranda, Fontes e Evolução do Direito Civil Brasileiro, Rio, 1981, p.93.

38. Ennecerus-Nipperdey consideram o Código Civil brasileiro a mais independente das codificaçōes latinoamericanas e registram que apenas 62 artigos têm sua origem no BGB. Anotam, porém, que "a ordenação das matérias tem ampla correlação como qúdigo Civil alemão, embora seja diversa a divisão em uma parte geral e uma parte especiar" (Derecho Civil, Barcelona. Bosch, 1947, vol I, p.108).

39. Ct. Pontes de Miranda,Die Zivilgesetze der Gegenwart,Band III, Brasilien Código Civil, Einleitung, p. XLI 
se ainda mais com o projeto de Antônio Coelho Rodrigues, de 1893, "amplamente inspirado", como diz Eduardo Espínola, "nos princípios predominantes na Alemanha. A clas sificação das matérias é exatamente a da escola alemã: tem uma lei preliminar, uma parte geral e uma parte especial. A lei preliminar compõe-se de 39 artigos e trata 'da publicação da lei e dos seus efeitos em relação ao tempo, ao espaço e ao objeto; a parte geral se subdivide em três livros: $1^{\circ}$. das pessoas; $2^{\circ}$. dos bens; $3^{\circ}$. dos fatos e atos jurídi; a parte especial tem quatro liuros $1^{\circ}$. das obrigaçōes; $2^{\circ}$. da posse, da propriedade e dos outros direitos reais; $3^{\circ}$ do direito da família; $4^{\circ}$ do direito das suces sões" ${ }^{40}$. Por trilha semelhante seguiu o pro jeto Bevilaqua, com a alteração, entretanto, da ordem das subdivisões da parte especial. Convidado pelo Governo Brasileiro no início de 1896 para elaborar anteprojeto de Código Civil, Bevilaqua começou sua obra em abril e a concluiu em novembro daquele mesmo ano. $O$ anteprojeto, no seu sistema, é claramente influenciado pela ciência jurídica alemã, anterior ao $\mathrm{BGB}$, e não propriamente pelo $\mathrm{BGB}^{41}$. E assim ficou, com as modificações que lhe foram introduzidas, até converter-se em lei e sua publicação em $1916^{42}$

14. Ao cogitar-se de ponderar a influência do romanismo ou de germanismo no Código Civil Brasileiro, não há dúvida que a balança irá pender para o lado da con-

tribuição do direito romano, quer seja o bebido nas suas fontes autênticas, quer o que se traduz no direito comum e na interpretação que a experiência histórica, em constante mutação, lhe foi atribuindo. $\mathrm{Se}$, no tocante ao sistema do Código Civil Brasileiro, a influência da ciência alemã - ou, se assim se preferir, do germanismo - como vimos, é especialmente importante, no seu aspecto substancial, entretanto, é claro que há nítida predominância de matéria extraída do direito romano. Os que tiverem a paciência de percorrer os comentários de Clóvis Bevilaqua ao Código Civil, detendo-se em cada artigo para examinar as referências preliminares que o autor faz à origem do preceito e em que ordenamentos jurídicos existe regra igual ou similar, logo verificarão a raiz romana da imensa maioria das disposições ali consignadas ${ }^{43}$.

15. Por certo, na parte geral, é mais forte a impressão da ciência jurídica alemã, notadamente: no tratamento das pessoas jurídicas, onde afloram as concepções orgânicas de Gierke, a par de estabelecer-se a da necessidade do registro para a personificação da sociedades e fundações de direito privado; no conceito de pretensão, elaborado por Windscheid, no seu célebre estudo sobre a ação do processo civil romano (Die Actio des röm. Zivilrecht von Standpunkt des heutingen Rechts -1856) que, no art. 75, aparece, entretanto, confundido com o de

40. Sistema do Direito Civil Brasileiro, Rio, ed. Rio, 1977,p. 18.

41. Nesse sentido, Pontes de Miranda, Fontes, p.85; Clóvis do Couto e Silva, op. citt., p.155. Por último, Cláudia Lima Marques, no seu belo ensaio Cem Anos de Código Civil Alemão : o BGB de 1896 e o Código Civil Brasileiro de 1916, RT 741/11-37.

42. A história pormenorizada do nosso Código Civil é retraçada por Clóvis Bevilaqua no Código Civil dos Estados Unidos do Brasil por ele comentado, Rio, ed. Rio, 1976 (ed. historica), vol l, p.12 ess.

43. Sobre as estatisticas das influências no Código Civil Brasileiro, por todos, Cláudia Lima Marques, op. cit., p.24 e ss. ação de direito material ${ }^{44}$; na enumeração das causas da nulidade do ato jurídico, no art.145, embora, quanto a esse ponto, o Código Civil Brasileiro seja bem mais conciso (ousaria até dizer, menos prolixo) do que o BGB, deixando, porém, de inserir no elenco que consigna, lamentavelmente, como o fez o BGB, no art. 138, a nulidade do ato jurídico praticado contra bonos mores.

Contudo, mesmo aí, na parte geral, muito particularmente na classificação dos bens e na conceituação e disciplina dos vícios da vontade (erro, dolo, simulação, coação), bem como da fraude contra credores, o destaque que assumem as concepções romanas é evidente.

16. Quanto ao direito de família, nem o direito romano, nem o direito germânico deixaram rastro expressivo no nosso Código Civil. O direito romano de família, do período classico, que Fritz Schulz chamou de "o produto mais impressionante do gênio jurídico romano" 45 foi profundamente alterado pelas concepções do cristianismo e pelas regras do direito canônico, implicando um atraso no processo do estabelecimento da igualdade entre os cônjuges que só neste século se cuidou de recuperar.
No que respeita ao direito de família do BGB, do mesmo modo como ao do nosso Código Civil, pode-se dizer que já nasceram velhos e voltados para o passado. $\mathrm{O}$ pensamento germânico e as instituições jurídicas alemãs, anteriores ao BGB, não trouxeram, também, soluções de importância para o nosso direito ${ }^{46}$. Caberá referir, entrentanto, que o regime de bens da comunhão universal, no direito patrimonial de família, corresponde à "comunhão de mão total" (Gesamthandgemeinschaft), do velho direito germânico, na qual, como em tantas de suas instituições, os interesses do grupo prevaleciam sobre o dos indivíduos, em contrasdte com o que geralmente ocorria no mundo romano ${ }^{47}$

17. No direito das coisas, a marca romana é dominante. Ela aparece muito nítida na posse, noção que é bem mais precisa do que a Gewere germânica, na proteção possessória, na propriedade em geral, nos direitos reais sobre coisas alheias. A influência germânica se revela, por outro lado, de modo peculiar, no trabalho realizado pela ciência jurídica alemã sobre o conceito romano de posse, definida, no art. 485, seguindo as linhas da concepção de Ihering, na distinção entre posse direta e indireta (art.486), na eficácia do registro na trans-

44. Só com a obra de Pontes de Miranda e, especialmente, só após a publicação da Parte Geral do seu monumental Tratado de Direito Privado na d́cad de 50 é que seŕ́ bem explicado no direito brasileiro o conceito de pretensão consistente na possibilidade de exigir que lade de exigir que geral e conceito indispensável para a compreensäo, por exemplo, da prescriçaoo, dos direltos formativos, das chamadas obrigaçóes imperfeitas ou dos direitos mutilados, dos direitos expectativos, do termo e da condição suspensiva, entre outras categorias
importantes do direito privado.

45. Derecho Romano Classico, Barcelona, Bosch, 1960, p.99. Veja-se, também, meu artigo Casamento e a Posição Jurídica da Mulher no Direito de Familia Romano do Período Clássico", in Revista "Direito e Justiça", vol. 15, p.97 e ss.

46. Cláudia Lima Marques, op. cit., p.33-34.

47. Sobre a subsistência da Gesamthandgemeinschaft no direito contemporâneo, vd. João Baptista Villela, Condomínio no Código Civil Brasileiro - Romanismo versus Germanismo, in Ferrero Costa, Raul, et alii - Tendencias Actuales y Perspectivas del Derecho Privado y el Sistema Juridico Latinoamericano, Lima, Cultural Cuzco, 1990, p.579-590.

Revista da Faculdade de Direito da UFRGS, v. 13, 1997 
missão da propriedade imobiliária e na constituição de direitos reais.

Não adotou o direito brasileiro, en tretanto, no que diz com a transmissão da propriedade imobiliária, a rígida separação existente no direito alemão entre os planos dos negócios jurídicos obrigacionais (que são, de regra, causais) e o dos negócios jurí dicos do direito das coisas, como o acordo de transmissão, que são abstratos. É irrecusável, entretanto, que, sob o aspecto lógico, deverá sempre haver uma diferença entre negócios jurídicos obrigacionais e negócios jurídicos de disposição (Verfügungsgeschäfte). Daí porque se tenha afirmado que tal separação de planos, no direito brasileiro, é meramente relativa, o que significa dizer que a invalidade do negócio jurídico obrigacional contamina a transmisssão do domínio, afirmando-se, assim, entre nós, a causalidade do acordo de transmissãa ${ }^{48}$.

18. A base do direito das obrigações é toda ela romana. É inegável, no entanto, que a noção que se tem hoje de obrigação, ou a que já se tinha à época da elaboração do nosso Código Civil, não é, e nem poderia ser, a mesma que os romanos conceberam. Muitas modificações profundas foram introduzidas, especialmente no modo de considerar o vínculo obrigacional, que sem pre conservou, no grande arco da história romana, a natureza pessoal que intensa e até cruelmente o caracterizou nos primeiros tempos, como atesta o partis secanto das

XII Tábuas. Quando os romanos afirmavam que "obligationum substantia in eo consistit ut alium nobis adstringat, ad dandum aliquid, vel faciendum, vel praestandum" (D.44.7.3) concebiam um laço jurídico entre pessoas determinadas. $O$ mandato ilustra bem essa maneira de ver a obrigação, pois as obrigações contraídas pelo mandatário só dele podiam ser exigidas, uma vez que, em todas as áreas do direito romano, a chamada representação direta só veio a ser admitida em hipóteses excepcionais ${ }^{49}$. Na generalidade dos casos, a representação era indireta, ou seja, se de mandato se tratasse, estabelecia-se um vínculo interno entre o mandante e o mandatário, mas jamais entre o mandante e o terceiro. Este estava ligado exclusivamente ao mandatário. Não será preciso dizer que o direito moderno rompeu essas limitações, não apenas para admitir plenamente a representação direta, que se tornou comum, como também para admitir a constituição de vínculos obrigacionais com pessoas indeterminadas ou só posteriormente determinadas, como se passa com os títulos de crédito ${ }^{50}$.

Aos alicerces romanos agregou o nosso Código Civil material provindo de outras influências, dentre as quais, por certo, as do direito alemão.São elas sobretudo perceptíveis no efeito vinculativo da proposta (art. 1.080), na estipulação em favor de terceiros (art. 1.098), na gestão de negócios sem mandato (art. 1.332), na possibilidade que tem o devedor de pagar a qualquer dos credores solidários (art.899), nas regras so bre o pagamento (art.930) ${ }^{51}$. Ao nosso di reito civil incorporou-se, também, a distinção germânica entre débito (Schuld) e responsabilidade (Haftung), a meio cami nho entre o direito das obrigações e o direito das coisas.

19. Finalmente, no tocante ao direi to das sucessões, também aqui a influência predominante é romana, tendo, porém, re cebido significativas contribuições do direito português e francês, mas modesto subsídio do direito germânico ${ }^{52}$

20. O Código Civil brasileiro, ao ex tinguir a vigência do direito romano em nosso país, determinou, também, o declínio do seu estudo entre nós. A disciplina de direito romano foi eliminada da maioria dos currículos de nossas faculdades de direito ou geralmente não consta dos daquelas que mais recentemente foram criadas. Não será exagerado afirmar, assim, que a influência do romanismo, na leitura de nossa legisla ção civil, se não desapareceu de todo, é quase que inexistente, efeito que, aliás, pro duziu a codificação, nos países cujo direito integra a família do direito romano.

Destino diferente teve, entretanto o germanismo. Após o nosso Código Civil, a interpretação que dele se fez e as obras que sobre direito civil se escreveram, foram, em sua grande maioria, apoiadas no direito francês, no direito italiano e no direito português. Creio não cometer injustiça ao dizer que a única voz que ainda mantinha viva

51. Veja-se Cláudia Lima Marques (op. cit.p.35), coligindo, sobretudo, as indicações de Pontes de Miranda (Fontes) 52. id.ib., p.35-36

53. A isso chama Cláudia Lima Marques de "novo germanismo" (op. cit., p.30). a tradição da Escola do Recife, na sua veneração pela cultura jurídica alemã na área do direito privado, era a de Pontes de Miranda. A ele se deve o renascimento do germanismo no direito civil brasileiro ${ }^{53}$. Isso acontece não propriamente em razão do que Pontes de Miranda escreveu até a primeira metade deste século, mas sim com o início da publicação, na década de 50 , do seu monumental Tratado de Direito Privado. Especialmente os volumes da parte geral do Tratado revelam um domínio assombroso da literatura jurídica alemã, não só da pandectística, como também da moderna, o que imprime às matérias neles tratadas uma precisão e um rigor científico até então nunca conhecido em nosso direito privado.

O transporte para o direito brasileiro da noção de Tatbestand, expressão traduzida por "suporte fáctico"; a classificação dos atos jurídicos de direito privado, com a distinções entre negócios jurídicos, atos jurídicos stricto sensu e atos-fatos jurídicos; o emprego das concepções orgânicas de Gierke no trato das pessoas jurídicas ("o diretor presenta, não representa a pessoa jurídica"); a análise da nova categoria dos direitos subjetivos, consistente nos direitos formativos, a que Emil Seckel deu forma definitiva, bem como a dos direitos expectativos; o exame meticuloso do conceito de pretensão, de Anspruch, com todas as suas importantes implicações; o esforço em demonstrar que, também no direito brasileiro, o acordo de transmissão da proprie- 
dade imobiliária é negócio jurídico abstrato - são algumas facetas de seu pensamento e das suas lições que bem exprimem o quanto sobre o seu gênio pesou a cultura jurídica germânica.

Não parece excessivo asseverar, portanto, que com Pontes de Miranda começam de novo a encher-se com o bom vinho da doutrina alemã os já envelhecidos odres do nosso Código Civil. Na verdade, a releitura do nosso direito civil, empreendida por Pontes de Miranda no seu Tratado, não demorou a refletir-se na jurisprudência dos tribunais nacionais, ao mesmo tempo que impressionava, também, toda uma nova geração de juristas.

$\mathrm{O}$ que hoje com mais facilidade se pode criticar na obra de Pontes de Miranda - e esse será talvez um ponto de sombra deixado pelo seu germanismo - é a sua concepção mecanicista do direito e o seu positivismo. Isso impediu-lhe de avaliar corretamente a importância de algumas cláusulas gerais acolhidas pelo $\mathrm{BGB}$, como, por exemplo,as que se extraem dos parágrafos 157,162 e. 242, relacionados com a boa fé (Treu und Glaube), ou do parágrafo 138 , que diz respeito aos bons costumes, censura que, aliás, em primeiro lugar se deverá fazer ao autor do projeto do nosso Código Civil e aos que colaboraram na elaboração do texto definitivo.

São essas cláusulas gerais que impedem que os códigos envelheçam prematuramente, pois são elas as portas abertas para a ética social, os canais por que penetram no direito as mudanças culturais e econômicas, os delicados sensores que adaptam os sistemas jurídicos às oscilações do meio a que se aplicam.

Contudo, a moderna doutrina civilista brasileira tem tentado introduzir no nosso direito os valores que se acham expressos naqueles preceitos do BGB, considerando-os como princípios imanentes ou implícitos em nosso sistema jurídico ${ }^{54}$.

Se a primeira onda de germanismo pode ser identificada na ciência jurídica alemã do século passado, que influenciou o nosso Código Civil, e a segunda no rastro deixado em nossa cultura pelo pensamento de Pontes de Miranda, caberá falar, ainda, de uma terceira onda, consistente na penetração que tiveram em nosso meio, após a edição do Código Civil português, de 1966, de forte inspiração germânica, as obras dos civilistas lusitanos. Mário Júlio de Almeida Costa, José de Oliveira Ascensão, João de Matos Antunes Varela, Antônio Manuel da Rocha e Menezes Cordeiro, entre outros, são juristas portugueses dos nossos dias, de sólida formação germânica, cujas obras, de larga circulação no Brasil, têm contribuído para que a leitura do nosso Código Civil continue a ser feita, de certa maneira, pelas lentes da ciência jurídica alemã, embora as adaptações sofridas ao ser recebida pelo direito português.

21. Concluo dizendo que romanismo e germanismo confluiram poderosamente na conformação do nosso Código Civil e, com maior ou menor vigor, continuam ainda a influir na sua interpretação e na modelação do direito civil brasileiro contemporâneo. Num mundo em que os avanços tecnológicos vão cada vez mais derrubando as fronteiras entre as nações, facilitando os processos de integração, talvez já tenha chegado a hora de pensar que essas divisões, como as de germanismo e romanismo, são meras expressões diversificadas - não do espírito de um povo, como de certa maneira pareceu, no início da Escola Histórica - mas do mesmo espírito vivo da humanidade. 